\title{
NIMBYS, NEWBIES, AND NON-CONFORMISTS: \\ LOCAL KNOWLEDGE IN COMMUNITY PLANNING
}

\author{
by
}

\author{
Kahlin Holmes \\ BA (Honours) Dramatic Art, Brock University 2013 \\ A Major Research Paper \\ presented to Ryerson University \\ in partial fulfillment of the \\ Master of Planning \\ In \\ Urban Development
}

Toronto, Ontario, Canada, 2016

(c) Kahlin Holmes, 2016 


\section{AUTHOR'S DECLARATION}

I hereby declare that I am the sole author of this MRP. This is a true copy of the MRP, including any required final revisions.

I authorize Ryerson University to lend this MRP to other institutions or individuals for the purpose of scholarly research.

I further authorize Ryerson University to reproduce this MRP by photocopying or by other means, in total or in part, at the request of other institutions or individuals for the purpose of scholarly research.

I understand that my MRP may be made electronically available to the public. 


\title{
NIMBYS, NEWBIES, AND NON-CONFORMISTS: \\ LOCAL KNOWLEDGE IN COMMUNITY PLANNING \\ (c) Kahlin Holmes, 2016
}

\author{
Master of Planning \\ in \\ Urban Development \\ Ryerson University
}

\section{Abstract}

Neighbourhood groups play a variety of roles in the communities in which they operate, including significant activities that contribute to community building and as agents of local knowledge in community planning processes. In a city with distinct socioeconomic lines and development patterns, the inclusion of a range of public voices representing the diversity of needs and community assets in planning processes is integral to ensuring decisions will be meaningful to those they impact most. This research considers how neighbourhood groups may contribute to community planning decision-making in Toronto through the conveyance of local knowledge and the potential role they may play through City Planning's processes for public participation.

Key Words: Neighbourhood Groups; community planning; local knowledge; public engagement. 


\section{ACKNOWLEDGEMENTS}

Sincere gratitude is owed to the many who, for better or worse, have been involved in the creation and completion of this research.

To begin with, I would like to thank my supervisor, Dr. Pamela Robinson, for her affirmation and support. Whose "gentle prodding" always felt more like a hug, and whose special form of guidance will continually inspire my future endeavours.

To Lily-Ann D'Souza of Lura Consulting for her thoughtful consideration and feedback as the second reader of this work.

My loved ones, who have always encouraged me to reach for my goals, especially in their thoughtful critique and "devil's advocacy" that prompts me to be both reflective and accountable. To Anthony, my day-to-day support, and whose humour and composure in response to my daily ups-and-downs brought balance to this journey.

And finally to Jack and Mr. Man, whose naps I partook in vicariously and whose antics were a source of much-needed comedic relief 


\section{Glossary of Terms}

\begin{tabular}{|c|c|}
\hline CCA & Coronation Community Association \\
\hline CCRA & Centennial Community and Recreation Association \\
\hline CIP & Community Improvement Plan \\
\hline CoTA & City of Toronto Act, 2006 \\
\hline CPLC & Community Police Liaison Committee \\
\hline DNY & District of North York \\
\hline DPS & Development Permit System \\
\hline EY & District of Etobicoke York \\
\hline HCD & Heritage Conservation District \\
\hline HVRA & Harbord Village Residents' Association \\
\hline MA & Municipal Act, 2001 \\
\hline MRA & Mimico Residents' Association \\
\hline NRRA & North Rosedale Residents' Association \\
\hline OMB & Ontario Municipal Board \\
\hline OP & Official Plan \\
\hline OPA & Official Plan Amendment \\
\hline $\mathrm{PiPs}$ & Planners in Public Spaces \\
\hline PPS & Provincial Policy Statement \\
\hline $\mathrm{RA}$ & Residents' and/or Ratepayers' Association \\
\hline SC & District of Scarborough \\
\hline SRRA & South Rosedale Ratepayers' Association \\
\hline TOEY & District of Toronto East York \\
\hline ZBL & Zoning By-Law \\
\hline
\end{tabular}




\section{TABLE OF CONTENTS}

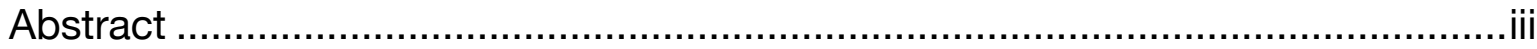

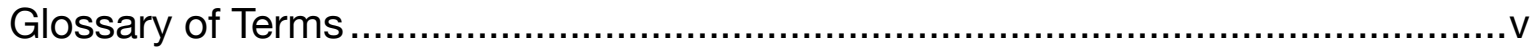

List of Figures and Tables .................................................................................

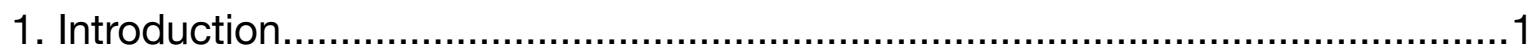

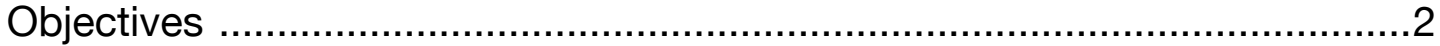

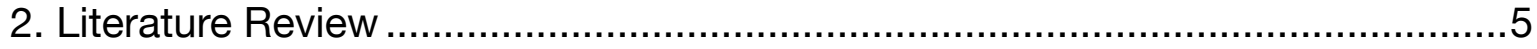

History of Public Participation ............................................................... 10

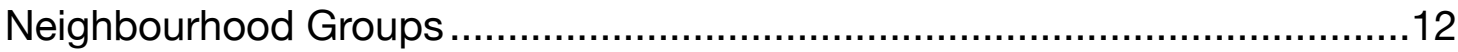

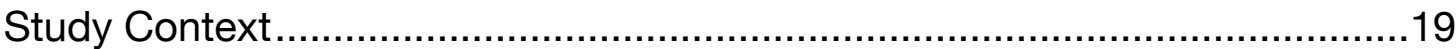

Civic Engagement in Planning Decision-Making in Toronto ...........................23

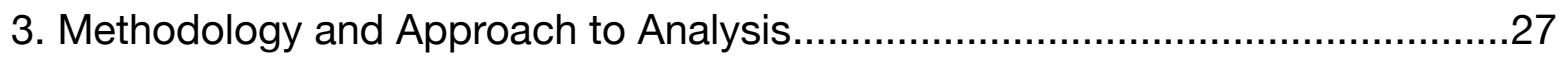

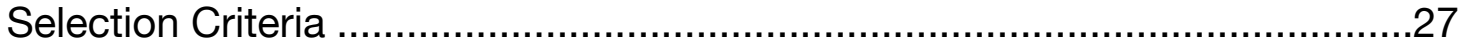

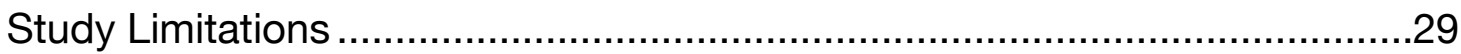

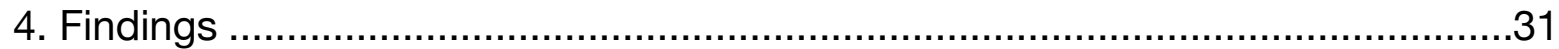

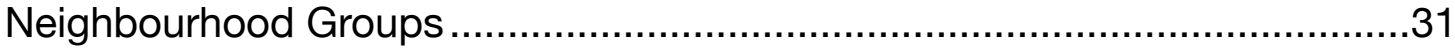

Missions, Objectives, Functions...........................................................31

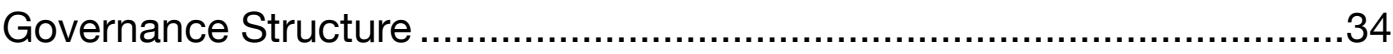

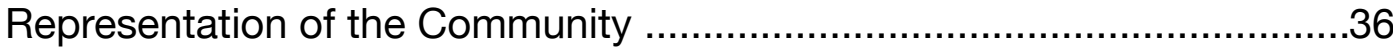

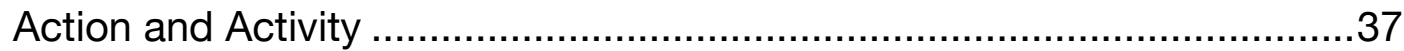

Neighbourhood Groups and Community Planning in Toronto ........................41

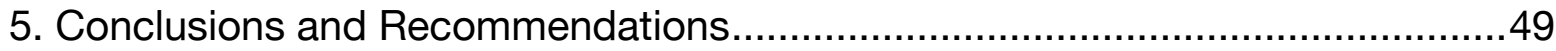

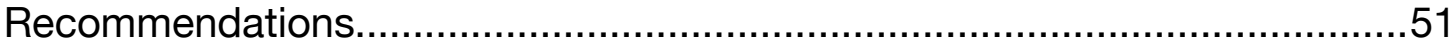

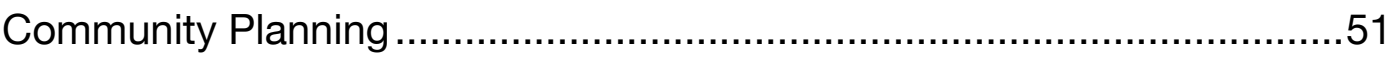

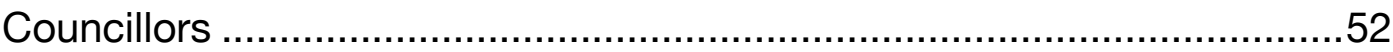

Neighbourhood Groups.....................................................................53

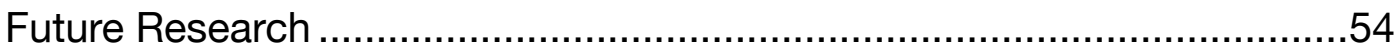

Appendix A: Toronto Official Plan Policy for Public Involvement............................55

Appendix B: International Association for Public Participation 2 Spectrum ...........56

Appendix C: Toronto City Planning Approvals Process.......................................57

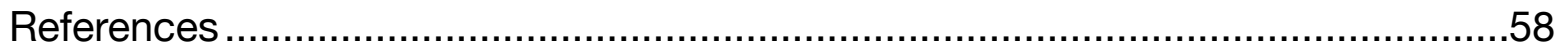




\section{List of Figures and Tables}

FIGURE 1: HULCHANSKI'S THREE CITIES

TABLE 1: SAMPLE STUDY GROUPS BREAKDOWN BY LOCATION CHARACTERISTICS

TABLE 2: Size OF BOARD OF DIRECTORS BY NEIGHBOURHOOD GROUP 


\section{Introduction}

...the beautiful is not landscape, or cityscape or architectonic; the beautiful is what people have built in the space between each other-a reciprocity, an exchange of ideas, and a shared vision.

Pier Giorgio Di Cicco Municipal Mind: Manifestos for the Creative City

Contemporary approaches to public participation have been increasingly inclusive of more diverse knowledge sources and communication methods. Local knowledge in particular has become recognized as an essential component of local planning processes and decision-making. Largely a result of the criticisms of traditional planning methods that are characterized by goal-driven, top-down procedures and which prioritize scientific and expert knowledge, shifts in models of public engagement demonstrate the willingness of planning practitioners and administrators to move beyond the "status quo" of placation.

Growing Conversations, Toronto's latest framework for engagement, shows signs of being in step with these trends. Through campaigns targeting specific groups previously underrepresented in the City's public participation efforts, the framework seeks to bring greater diversity to discussions of community planning and build the capacity of such groups to engage in more meaningful ways. The four-pronged strategy of Growing Conversations has embraced innovative communication tools, accessible data sharing, and targeted outreach to visible minorities, newcomers and youth with the ambition "to become the most engaged city in North America" (Keesmat, 2015). Notably, included in their outreach strategy are efforts to forge relationships with traditionally underrepresented stakeholders in the city. Their Youth Engagement Strategy, for example, worked with ten Torontonians between the 
ages of 18 and 29 to better understand how to include public members of this age group in city building. This is meant to bring greater representation to a process found to be typically dominated by by homeowners over the age of 55 (City of Toronto, n.d.).

A wide range of local voices is essential to identifying community issues across diverse neighbourhoods and ensuring that changes in the urban fabric are meeting their present and future needs. The crucial information the public brings to planning conversations is their knowledge of the communities they live in and interact with. However, planning processes based on traditional participatory methods have not historically been conducive to the sharing and application of local knowledge. Over the past 25 years planning practitioners have recognized and implemented such strategies into engagement processes and it is important for our profession to document and understand these changes. This research asks: Are we seeing signals that Toronto's participatory approaches in urban planning go beyond the "status quo" and seek more meaningful engagement with residents? To answer this question this research examined City Planning's engagement of neighbourhood groups in development consultation processes, Secondary Plan and Community Visioning exercises, parks planning, and city-wide engagement initiatives that document the exchange of technical and local knowledge.

\section{OBJectives}

The research considers how local knowledge is conveyed through neighbourhood group participation in community planning and development through an evaluation of the constitutional objectives and newsletter articles published by neighbourhood 
groups and their responses to planning proposals. It investigates how such groups procure and convey local input to community planners through their activities. This research is necessarily situated within a contextual framework, provided by a review of recent studies on urban growth patterns and the City's socioeconomic landscape. It considers how neighbourhood groups present both a challenge to and opportunity for Toronto City Planners to acquire more meaningful input from a broader range of residents.

This paper starts with a review of the literature pertaining to the trajectory of public participation in planning from the 1950 s to the emergent forms of the present. Attention is given to the challenges and criticisms of the traditional "rational" planning model and the strategies that have formed as a response. The collaborative lens is of particular interest to this exploration of contemporary public participation in planning and thus calls for some commentary on its emergence and significance.

This paper next turns its focus to a general review of the history and functions of neighbourhood groups based on the limited availability of previous research. Despite the shortage of material, it is a worthwhile starting point from which this research can augment and enrich our understanding of their relationship to planning practices in Toronto and beyond.

Planning history and theory is augmented by an examination of the relevant planning and development features of the study context. Toronto's socioeconomic landscape, current development patterns, and regulatory frame provide critical insight into the factors that influence why, when and how public engagement takes place and who is included and left out of those processes. 
The next section describes the methods of data collection and analysis as it pertains to this research. Content analysis was chosen as the appropriate method given the scope and limitations of the research project.

Section four reports on the findings of the research, pursuing themes of local knowledge and collaborative planning practices through the activities and objectives of neighbourhood groups and Toronto urban planning engagement practice. This leads into the conclusions section which discusses the challenges to effective collaboration and opportunities for refinement revealed by the research. Based on the analysis and findings, recommendations for future action are provided to Toronto Community Planners, Councillors, and neighbourhood groups. 


\section{Literature Review}

Similar to its American neighbour, public participation in Canada is rooted in democratic principles and has emerged from a history of civic rights and grassroots movements of the late 1960s. In the United States, the roots of public participation in planning may be traced to the Urban Renewal movement of the 1950s and '60s. It was the activism, grassroots organizing and civil rights movements of the latter half of the 1960s, however, that caused participation to shift from the exclusive entitlement of elected officials to emerge as a right of the public (Burke, 1968). The shift toward formalized participatory rights is regarded as a significant link between representative and participatory democracy (Sanoff, 2005). Sanoff (ibid) highlights the significant role of the United Nations in pursuing the creation of opportunities allowing for the political involvement of all people in the development process. Woodford and Preston (2013), whose research focuses more specifically on public participation in the context of Canadian policy and decision-making, contend that participation in Canada was not intended to replace representative governance but rather to supplement it: "As a democratic tool, participation is [...] a contradictory process in which the state encourages citizens to become involved but then leaves them dependent on government officials for access, information and action" (p. 346). This distinction points to a number of issues that challenge the notion of participatory democracy and can be identified in more recent inquiries into the theoretical foundations of planning and its participatory processes. The emergence of these criticisms forms the basis for much of our contemporary participatory programs, as will be explored in the subsequent sections. 
Arnstein's Ladder of Citizen Participation (1969) is perhaps the most widely cited criticism of the failure of public participation to meaningfully involve citizens and facilitate their effect on outcomes. For Arnstein the influence of power is essential to any discussion of participation and thus, in her research she argues that genuine participation only occurs when decision-making bodies yield some of their own power to the citizen participants. The author employs the metaphor of a ladder with eight rungs to illustrate the degree to which a process affords decision-making power to citizens ranging from "non-participation" to "degrees of tokenism" to "degrees of citizen power" (p. 217). The first five rungs of the ladder-manipulation, therapy, informing, consultation, and placation-are levels of participatory activities that may be considered status quo efforts to engage the public as they lack legitimate opportunities for the public to influence planning outcomes. Partnership, delegated power and citizen control on the other hand permit greater public authority over decision-making. Researchers have employed the ladder framework to evaluate practice and gauge whether a process has merely maintained the status quo of engagement, or whether it has transformed practice by yielding a greater amount of power to the citizen stakeholders involved (Halvorsen, 2003; Hulchanski, 1974; Kopetzky, 2009; Peterson, 2012). Such research forms the basis from which many critics of conventional participation programs have called for the redistribution of power to achieve greater equity in plans and programs (Davidoff, 1965; Krumholz, 1982; Sanoff, 2000). Notable among these is Davidoff's appeal to planners to advocate for disadvantaged communities excluded from public deliberations (1965). The pursuit to further democratize public participation and the redistribution of power among stakeholders in 
planning processes is thus essential to understanding contemporary approaches to public engagement.

Today's participatory processes and consultations have been largely shaped by "the communicative turn" in planning theory that sought to address criticisms of inequity and lack of public power (Healey, 1992). Healey dubbed this "turn" after Habermas' 1981 text which describes an alternative form of rationality distinct from the dominance of scientific rationalism in prevailing forms of practice. The author reviews several distinct directions in which planning theory has attempted to address the challenges of conventional practices. She argues that it is only communicative strategies that strive to achieve conditions of authentic dialogue (through "ideal speech situations") and seek consensus through debate that allow practice to move beyond the power struggles of traditional approaches. Habermas' conditions for ideal speech conditions promote the inclusion of diverse voices who are given the opportunity to participate by voicing questions and assertions, and who may not be subject to the influence of those with power outside of the process (as cited in Innes \& Booher, 2010). John Forester (1982) further promotes the role of communication in contributing to a fair process and greater distribution of power in planning and thus carries forward the torch of advocacy previously borne by Davidoff. Forester notably argues that planners must bear the responsibility for distortions in communications that stem from the exercise of power and result in inequitable planning outcomes. His work calls attention to the ways in which planning is not simply about a "means to ends" exercise , but rather about the process of communication between planners and stakeholders. 
In what seems to be a further evolution of the communicative turn, researchers and practitioners have identified the emergence of a practice marked by efforts that are distinctively collaborative. Studying participation through extensive field work, researchers note a shift away from the linear, goal-oriented approaches toward a more socially constructed process (Innes and Booher, 2010). Whereas the traditional model of participation is determined by goals prescribed by elected officials and their administrators and relies heavily on objective evidence and expert knowledge, the new trend in public participation seeks to incorporate a greater degree of local and lay knowledge in a shared process of information sharing and deliberation (ibid).

In addition to expressing characteristics of communicative action such as authentic dialogue and collective deliberation, collaborative approaches as postulated by Innes and Booher (2005) also draw on negotiation theory, alternative dispute resolution, interpretive knowing and complexity science to understand how participatory processes have evolved since the communicative turn. Based on years of research and experience in public participation processes the authors propose three criteria that are "critical to whether a collaborative process can be collaboratively rational, productive of socially valuable outcomes, and adaptive to the opportunities and challenges of its unique and changing context" (2005 p. 35). The authors dub this the DIAD theory for collaborative rationality.

The first condition of DIAD is that a diverse range of stakeholders must be involved in the process. Importantly, this means that along with including those who might be directly affected by neighbourhood activity both "deal makers" (ie. those who have the authority to implement a plan of action) as well as "deal breakers" (those who 
have the power to interfere with a plan) must also be present (p. 36). Second, there must be recognition among participants of their interdependence on one another in having their interests met. The final condition stipulates that there must be the opportunity for authentic dialogue between participants that reflect the "ideal speech situation" postulated by Habermas. Applying this to participatory processes, deliberations must:

1. Allow for agents to have equal opportunity to speak and be listened to;

2. Be inclusive of all major interests and knowledge;

3. Be open to challenge, question, or clarification of assertions and;

4. Be free from domination of those with power outside the process.

These conditions represent principles to be aimed at rather than an ideal that may potentially be achieved. Nonetheless, the DIAD theory provides an appropriate model by which to assess the capacity of participatory processes to produce meaningful outcomes representative of local input. The DIAD conditions for an inclusive, deliberative, and reciprocal process thus provide a framework conducive to examining City engagement programs at the outset of its announcement to become "the most engaged City in North America".

The consistent improvement, expansion, and democratization of public participation of the past 60 years demonstrates a general consensus in the literature of its inherent value. Improving the scope and effectiveness of engagement in planning decisions is thus seen as a meaningful pursuit in planning practice. Studies often seek to identify the successes and failures of participation, evaluate particular strategies, and propose improvements for future trial. The shift in practice and theory thus 
represents an attempt to move beyond the status quo of engagement, wherein the public perceives as well as truly lacks legitimate leverage to affect planning decisions. The International Association for Public Participation is an organization whose work is focused on improving the practice of public participation and is representative of the shift in participatory practice toward more communicative and collaborative processes. The Association provides an additional tool that may be considered an update of Arnstein's Ladder of Participation that takes into consideration the shifting perspective. This is the Public Participation Spectrum (Appendix B) that recognizes levels of participation will vary depending on the goal, and stipulates the responsibility of administrators to the participating public. Rather than a hierarchical ladder the spectrum is comprised of five participatory actions-Inform, Consult, Involve, Collaborate, and Empower-that have distinct goals and tools to achieve outcomes.

\section{History of Public Participation}

Citizen participation has its roots in human rights, both in Canada and the Western context generally, but there is further basis for involving people in planning decisions beyond its ethical foundations. Much of the literature suggests that underlying the rationale for participation is the widely held perspective of its intrinsic egalitarian value. It is thus often associated with the ideals of functioning democracy in which citizens actively share in the process of city building. Stivers (quoted in Day, 1997) traces this understanding back to Aristotle who postulated that citizen participation, as it involves the "highest human capacities," embodies "the good or virtuous life" (ibid, p. 424). Regardless of this canonical endorsement, participation continues to be understood both among academics and their research subjects as the 
"cornerstone of democracy" (Woodford, 2011 p. 346; see also Day, 1997; Faga, 2010).

This is captured by notable urbanist Jane Jacobs when she wrote "cities have the capability of providing something for everybody, only because, and only when, they are created by everybody" (1961, p. 238).

Further, participation not only provides opportunities for the public to be involved in decision-making, but serves to narrow the gap between government administrators and the public. Given its origins in grassroots organization and democratic action, participation is seen as a systematic safeguard to ensuring a fair process underscores government decisions (see the following section). An increased awareness of institutionalized inequity delegates a greater degree of responsibility on participatory processes to bring to light the needs and preferences of groups that have hitherto been disadvantaged. These needs, notes Innes and Booher, may only "come on to the radar screen during an open participation process" (2005, p. 421).

By spending time with residents to hear concerns, share information and allow for input into community planning decisions, participation fosters public support for projects at the same time that it increases the legitimacy of the project at hand. It serves to justify decisions by allowing planners to cite the scope and putative democratic nature of the process. (Day, 1997; Faga, 2010; Halvorsen, 2003; Innes and Booher, 2005). Communicative action through public participation thus cultivates more effective working relationships between residents and municipal planners as they recognize their interdependence in achieving individual goals. Further, including the public has the potential to improve plans, decisions and service delivery by incorporating the knowledge of those with first-hand experience of a community (Faga, 
2010; Innes and Booher, 2005; Margerum, 2011). Understanding the preferences of locals allows decision-makers to create plans or programs that respond to the specific needs of a community. Thus, implementing local knowledge allows for more effective and appropriate planning decisions (Smith, 2011).

Importantly, planners are required by law to incorporate public consultation in planning processes. In Ontario the planning process is set out in the Planning Act and City of Toronto Act, 2006 (CoTA) both of which include specific requirements for public consultation (see Appendix A). The Planning Act (2014) requires that all municipalities provide application materials and notice of meetings to the public in advance of public meetings regarding amendments to various community planning items including Official Plans, Zoning By-laws, and Plans of Subdivision. The CoTA similarly guides participatory processes by stating values and directives for ensuring a fairness and transparency. Together these acts are responsible for when and how participation takes place, and ensuring that the voices of the public have an opportunity to respond to change and development in their communities.

\section{NEIGHBOURHOOD GROUPS}

It is often neighbourhood groups who step up to claim representation as the "voice of the community" in response to planning proposals. As their communities are the focus of neighbourhood group organization and mobilization, such groups present an opportunity to identify how local knowledge is deployed through planning processes and decisions. 
Neighbourhood group is the term used in this research to broadly refer to what have historically been called Ratepayers' or Residents' associations. While there is not one definition that is agreed upon in the literature, the definition provided by Logan and Rabrenovic (1990) is employed here. The authors define such groups as "civic organization[s] oriented toward maintaining or improving the quality of life in a geographically delimited area" (ibid). While Residents' and Neighbourhood Associations are more common and current designations in the literature, this study employs the term neighbourhood groups to avoid the use of potentially value-laden terminology that precludes the membership of renters. The alternative allows for the inclusion of groups whose membership is comprised of both homeowners and renters the latter of whom make up close to half of Toronto's tenancies (Statistics Canada, 2011).

The employment of "neighbourhood groups" also allows for the consideration of groups that exist along a spectrum of political orientations toward community organization that has roots in both the upper and lower classes of historical residential development (Peterman, 2000). According to Peterman, organizations in upper class neighbourhoods were formed by homeowners on the advice of real estate developers to protect property values and the exclusivity of their neighbourhoods. Community building and advocacy was the focus of poorer communities concerned with improving housing and social conditions (ibid). The resulting organizations of these groups are the foundations of contemporary residents associations and community organizations. However while both have stakes in community development and planning there is a notable divergence in the issues and concerns that motivate groups to participate in 
city-led processes. The worst-case scenario is the aggressive NIMBYism (not-in-myback-yard) that prevents the establishment of much-needed social services in communities, such as transitional housing or drop-ins. Toronto Star columnist Edward Keenan called attention to the "NIMBY paradox" in his series on the subject which pointed to the ways in which NIMBYs can be over-reactive and "toxically afraid of change" but whose presence may serve as a litmus test for a great community (Toronto Star, 2010). The use of "neighbourhood groups" for this research therefore is to include the range of organizations that have formed from these divergent histories.

Whether neighbourhood groups tend toward NIMBYism or Communitarianism 1 depends largely on their relationship with the wider community and the City departments with which they engage, and the participatory and political roles they play within these relationships. When the City seeks public input neighbourhood groups can play an important role in connecting the government directly to its citizens through their own communications and outreach programs and in assisting in the implementation and delivery of plans and programs. In this context, neighbourhood groups and government can be understood as partners. Along with extending the outreach of government communication and increasing the likelihood that it will reach desired audiences, neighbourhood groups can act as a kind of trust-filter for this material in their capacity as a neighbour to others in the community. As public engagement is often challenged in garnering able and interested citizens to participate, neighbourhood groups can assist by distributing information to their member audience. Along with gathering inputs into the process, groups can assist in the delivery and

\footnotetext{
${ }^{1}$ A 20th century ideology wherein the community or society is prioritized over the needs of the individual
} 
implementation of policies and programs from the city. Examples range from action associated with by-law adherence to neighbourhood compost delivery programs. Many groups in Toronto, for example, have been active in implementing the City's Ash Management Program which seeks to control the impact of the Emerald Ash Borer (an invasive insect) on neighbourhood trees.

Established neighbourhood groups also tend to have a wealth of experience that allows them to play a mediatory role between citizens, government and developers. Such experience enables them to "translate" unfamiliar bureaucratic processes and generally introduce planning concepts to community members. This contributes to a safe space for communities to learn and be introduced to community planning and decision-making processes. In this role neighbourhood groups can also facilitate problem-solving, negotiate, and resolve conflict between residents, municipal agents and developers (Vandbelt, 2002). The position is significant in dispersing power and promoting democracy, notes Jane Jacobs, who sees this "broker" role as crucial in allowing communities to access the power of city government (qtd. in Peterman, 2000).

The formation of neighbourhood groups is often a result of communities seeking to formalize and coordinate an advocacy mission, which ranges on a scale from neighbourhood protection to progression. In their advocacy role groups assist in identifying and speaking up for community needs such as public services and facilities. This is most evident in consultation processes where groups may negotiate for community amenities and services in exchange for group support. They seek to improve the quality of life for residents, as well as promote neighbourhood identity. Groups seeking to enhance or keep up standards of living report on general 
infrastructure and maintenance concerns, as well as stimulate social and economic improvements. This can produce valuable outcomes in the physical spaces of the neighbourhood by initiating municipal action through policy and programs.

From the other end, neighbourhood groups can also be advocates on behalf of City-led initiatives. This role overlaps with the mediating role of neighbourhood groups. Advocating City programs and plans among community members can attract participants and lead to more successful program implementation. Common examples among Toronto neighbourhood groups include the promotion of public meetings or service interruptions through group newsletters or emails distributed among members.

Program implementation requires substantial organizing and mobilizing, and through these efforts neighbourhood groups can be key agents of local capacity building. Knowledge-sharing between members of the community and with planners works to build the social, political and technical skills of the community that allows them to more actively participate in decision-making processes. Both the group as a whole and individuals benefit from this experience by building personal confidence which allows for more meaningful input (Vandebelt, 2002). Capacity building facilitates community empowerment which contributes to the degree of control citizens exert over a decision-making process. Peterman's experience in resident management found that empowerment among individuals can be associated with three distinct meanings of the term and three political perspectives: conservative, liberal, and progressive (2000).

The conservative, who emphasizes the role of private property in maintaining social order, associates empowerment with ownership (Perin, as cited in Peterman, 
2000). The process of empowerment in this perspective is through liberation of one's dependency on bureaucratic systems and to become an owner of property. Control over and protection of property rights are thus central to the conservative.

Neighbourhood organization in this view is a tool, a "public means to private ends" (Peterman, 2000, p.37). In the case of the liberal, empowerment occurs via the distribution of power through increased access to government decision-makers. They do not aim to take full control or ownership over property, but rather seek adequate power to affect outcomes that impact their communities and daily lives. In this view, neighbourhood organizations are a conduit for participation. Those on the political left, the progressives, seek empowerment through the appropriation of power from their oppressors. Empowerment in this view is equated with complete control and organizing through neighbourhood groups is a way to take power back and seize control over their futures. While Peterman outlines these political perspectives quite distinctly, it is important to note that it is more likely that groups, made up of individuals representing a variety of backgrounds and experiences, exist on a political spectrum rather than representing pronounced political stances (right, centre, left).

The roles that neighbourhood groups play in their communities is telling of how local knowledge is produced and conveyed to municipal administrators. Through community building and social activities, groups spend time with other members and residents and have the opportunity to learn about the strengths, weaknesses, and needs of the neighbourhood. Through advocacy, mediator, and partnership roles, often played out on the community planning "stage," groups are able to impart this local knowledge. The roles played by neighbourhood groups, therefore, also allows us to 
understand what kind of or whose local knowledge is transmitted through neighbourhood group engagement in urban planning.

In Toronto neighbourhood groups represent a legacy of grassroots activism for their role in preventing the establishment of the Spadina Expressway and saving Old City Hall in the 1960s. The contemporary iterations of these groups continue to be active in the realm of city's development and community planning, stopping Wal-marts and wind turbines from moving into their neighbourhoods and view corridors. There are even reports of a resurgence of neighbourhood groups as residents seek opportunities to voice their concerns with regards to change, wanted or unwanted, in the city (Toronto Star, 2014).

Despite extensive past and present engagement in Toronto, there is a gap in research by academics and City staff regarding the role that these groups play in the City's current community planning processes. Only one other recent study has investigated the role between associations and Toronto Planning (Wynveen, 2015). Through case studies Wynveen's report provides valuable insight into the response and activities of neighbourhood groups in the City. The report at hand is an attempt to build on this research. It similarly investigated the relationship between selected neighbourhood groups and community planning, but with the particular aim of gaining insight into the City's public engagement efforts. 


\section{STUdY ConTEXT}

Toronto has particular challenges when it comes to engaging its residents in planning. How and whether the public participates depends largely on the type of change being proposed in relation to current neighbourhood characteristics and patterns of development. Recent studies have found that Toronto is characterized in large part by its neighbourhoods, which have both particular built form features as well as development patterns and distinct socioeconomic divisions (Hulchanksi, 2010). The demographic landscapes of the city provide crucial information about who are, or are not, consulted through Toronto's engagement efforts and hint at the kind of issues that may be of interest to residents across the city. The following section considers these socioeconomic features as well as patterns of development in the city and the influence of amalgamation on Toronto's governance capacity.

In 1996 the Ontario government ruled that the region of Metropolitan Toronto would amalgamate it's 6 constituent municipalities to form a single-tier municipality. In 1998, East York, Etobicoke, North York, Scarborough, York and the City of Toronto were dispersed and reformed as the new City of Toronto. Amalgamation involves "the involuntary or forced merger of smaller local governments with a larger municipality to form a large metropolitan area" (Schwartz, 2009, p. 483). It is believed that amalgamation brings significant costs savings by eliminating duplication in services and simplifying local government by merging smaller government units into a single larger one. This process produces significant impacts on local governance and citizen participation. In the case of Toronto, despite the establishment of local community planning councils as a measure to ensure adequate access to councillors prior to 
amalgamation, it has been found that the new scale has distanced citizens from government and resulted in decline in participation (Slack and Bird, 2013; Côté, 2009). In addition to straining the city's operating budgets, amalgamation has limited opportunities for participation between decision-makers and constituents. It diminishes government representativeness and accountability and most notably in the context of this research, it presents a challenge to reorient the City's ability to engage residents. In addition to its distinct geographical and built-form districts, a recent study in Toronto looking at income changes over 35 years has uncovered a growing disparity in the socioeconomic landscape of the city's neighbourhoods. Hulchanski's Three Cities Report (2010) observed a spatial division that connects demographic characteristics, physical social service infrastructure needs and patterns of income. The findings, based on census data at the census-tract level, introduce a city divided into three groups City \#1, City \#2, and City \#3, depicted in Figure 1 (following page). The research demonstrates that wealth in the city is concentrating in the downtown core (City \#1) where there is greater access to transit, services, and amenities, while low-income earners have concentrated predominantly in the city's Northeast and Northwest quadrants. In addition to these spatial concerns is the shrinking demographic of middle income earners (ie. incomes closest to Toronto's Census Metropolitan Area average) found in City \#2. High and low income earning populations, on the other hand, have grown. City \#3, where neighbourhood incomes decreased 20\% or more between 1970 and 2005, has experienced the largest population growth along with a dramatic increase of immigrants over the study period, from $31 \%$ to $61 \%$ of foreign-born residents. In City \#3, 34\% of the population identify as white, while $47 \%$ identify as 


\section{Change in Average Individual Income, City of Toronto, 1970 to 2005}

Average Individual Income from all sources, 15 Years and Over, Census Tracts

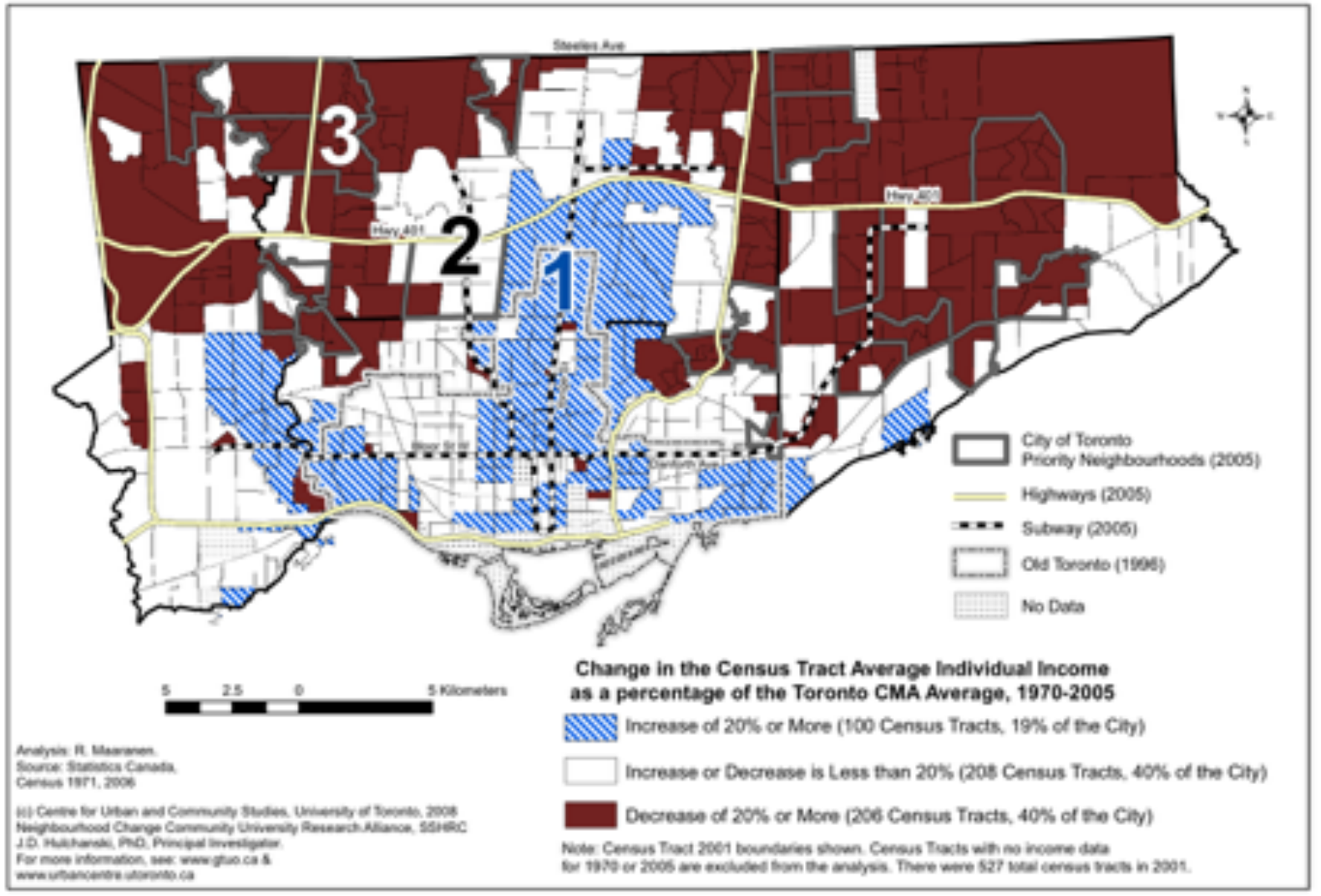

FIGURE 1: HULCHANSKI'S THREE CITIES,

Black, Chinese or South Asian. City \#1 on the other hand is disproportionately white $82 \%)$ and saw a decrease of $7 \%$ in foreign-born residents since 1971.

These findings reveal a racialized spatial divide, where visible minorities and newcomers predominate in lower-income neighbourhoods underserved by city services such as transit and other physical and social infrastructure. Hulchanski's report exposes Toronto as "a city of disparities," wherein wealth is increasingly the deciding factor of where one chooses to live, and where essential services, amenities and quality of life factors are increasingly decided by the power of wealth. Given the weakness of planning practice to the influence of power the ability to "buy choice" in 
Toronto is thus problematized by these discoveries and is significant in the following consideration of engagement practice with neighbourhood groups in the city.

In an effort to reduce development on greenfield lands and adapt to growing populations, Ontario initiated The Growth Plan for the Greater Golden Horseshoe in 2006. The plan set a $40 \%$ intensification target formalized through policy that directed municipalities to look to their already urbanized areas to accommodate new residential growth. In this view intensification is understood to achieve certain benefits, such as limiting development in greenfield areas that serve other agricultural, ecological, and social purposes. It is said to reduce reliance on automobile usage and increase other modes of transportation such as walking, cycling and public transportation that tend to have less environmental impacts. It also allows for more efficient use of surplus urban infrastructure capacity including both "hard" (sewer systems, utilities) and "soft" (schools and social services) infrastructure (Burchfield, 2014). In taking on both large numbers of new migrants to the city and increasing levels of economic activity, it is estimated that Toronto will grow by at least 2 to 3 million during the next generation (Desfor, 2006) and is currently Canada's largest housing market (Rosen and Walks, 2014). As a result the city has experienced a large development "boom" particularly in the form of condos. The spatial distribution of development investment has resulted in inconsistent patterns of development across the city (Wynveen, 2015). As some areas of the city experience gentrification and economic stimulation, others have been left to stagnate (ibid). In examining Toronto's engagement practices, therefore, it is necessary to grasp that the issues and needs will drastically vary between communities according to the kind of neighbourhood change they have been experiencing; on the one end 
rapid growth, or on the other, slow decline. Current built form characteristics, growth targets, and population changes are all significant facets that determine who shows up, why they participate, and what such residents might seek as an outcome from engaging in community planning.

\section{Civic Engagement in Planning Decision-Making in Toronto}

Civic engagement in planning processes in Toronto is mandated through the Ontario Planning Act and City of Toronto Act. The Planning Act requires the City to hold one meeting with the public when considering potential changes to the Official Plan, Zoning by-laws and Plans of Subdivision. This includes City-initiated amendments. Toronto's Official Plan outlines policies that speak to its approach to public involvement in Section 5.5 (Appendix A). It promotes an inclusive process that recognizes Toronto's ethno-racial diversity and encourages additional consultation meetings with City Staff as well as at least one public meeting in addition to what is required by the Planning Act. Finally, it promotes timely and transparent information-sharing throughout the approval process by encouraging the use of clear language and provision of materials to public in advance of meetings.

Public input into Official Plan or Zoning By-law amendments is obtained primarily through consultation and public meetings with the public, outlined in the City's process for planning approvals (Appendix C). Items specific to certain geographic areas of the city are often delegated to one of four Community Councils in the city (North York, Etobicoke, Scarborough, and Toronto and East York). Community Councils report and make recommendations to City Council but have limited decision- 
making power. During public meetings and consultations the public is encouraged to consider and discuss planning applications for Official Plan or Zoning By-law amendments. These events are opportunities for the public to ask questions of planning staff, provide feedback and make their views known through written or oral submissions. The decision-making power over planning in the city is the authority of City Councillors, who are obligated to consider public feedback when making decisions regarding planning items. Section 53 of the Planning Act grants decisionmaking power to a decision-making body known as the Committee of Adjustment for items that do not require Official Plan amendments, such as minor variances. These committees are made up of citizen-members who consider items such as plans of subdivision, property severance, easements and right-of-ways, and plans of condominium. Appeals to CoA items are frequently made to the Ontario Municipal Board, however, which significantly diminishes the group's decision-making authority. Toronto's ongoing efforts to refine its engagement with citizens presents an opportunity to assess its capacity to acquire and implement local knowledge through planning decisions. The current iteration of these efforts can be traced to former Councillor David Miller's discussion series which sought local input from Torontonians who included residents of the recently amalgamated municipalities of Etobicoke, York, East York, Scarborough, North York, Metro, and Toronto. The series was an essential first step in developing a framework for public engagement in Toronto based on the principles of collaborative decision-making, accessibility, continuous improvement in citizen participation and community capacity-building (Building the New City of Toronto, 2001). 
In 2003 Miller took office as the Mayor of the City, and in 2005 Toronto's City Manager began work on developing a Civic Engagement Strategy at the behest of the Governing Toronto Advisory Panel. The Strategy was to provide a definition of civic engagement in the context of the City's operation and service provision, establish an inventory of engagement activities in the City and develop performance indicators to better assess its engagement with citizens. The Strategy was developed through extensive proposal and review stages and included research on best practices, and workshops and training provided to staff engagement practitioners. The resulting Civic Engagement Strategy was launched in 2006 and sought to better inform both public participation and decision-making at the City.

Launched in 2014, Growing Conversations: Making Engagement Work is the latest update to Toronto's engagement programs with the ambitious goal to "make Toronto the most engaged city in North America" (Keesmat, 2015). Noting an "atmosphere of distrust" among public participants who tended to perceive City Planning as "merely a processor of change" the proposed model is meant to increase mutual understanding and trust between stakeholders and City Planning (City of Toronto, 2013). The expectation is that a strong working relationship would improve the effectiveness of collaborations and the planning processes generally.

Growing Conversations is comprised of four components which relate to the policies of the Official plan and advance the newly established goals of trust building and improving the effectiveness of planning processes:

- The Ethnic Media Strategy focuses on newcomers to build their capacity to engage in planning and ensure their voices are at the table in decision-making. 
- The Youth Engagement Strategy targets youth aged 18-30 with the vision of mobilizing a new generation of citizens engaged in city building.

- The Stakeholder Partnership Strategy seeks to partner with organizations to strengthen the City's engagement reach to the "under-engaged", hard-to-reach groups in the city: youth, newcomers, and low-income earners.

- The Open Data Framework seeks to open up City data such as Geospatial information, maps, and reports to the public.

These strategies demonstrate an attempt by the city to create a more accessible and accountable government and to achieve more proportional representation relative to the demographics of the city. A poll conducted by Ipsos Reid found that the majority of participants in Toronto's planning processes were white, male homeowners over the age of 55 (Keesmat, 2015). This a significant disparity with Toronto's mostly foreign, non-white population. According to most recent census data $49 \%$ of the City's population was born outside of Canada, $49 \%$ identify as a visible minority, $74 \%$ are under the age of $55,52 \%$ identify as female, and nearly $40 \%$ are renters (Statistics Canada, 2011). By focusing largely on incorporating those who have previously gone underrepresented in planning processes, the City's engagement efforts demonstrate a move toward the inclusion of diverse knowledge sources. 


\section{Methodology and Approach to Analysis}

This study is based on analysis of Neighbourhood Group and City documents that pertain to the organizational makeup and activities of groups and the engagement activity of Toronto City Planning. As a methodological approach, qualitative content analysis allows one to identify themes from large amounts of text in order to draw comparisons between sources (Neuman and Robson, 2009). Furthermore, it focuses analysis on broader issues such as latent meanings, motives, and purposes. Through a coding procedure, themes are identified based on the appearance of words or particular content. In Summative content analysis, codes are established before analysis occurs, while in Conventional content analysis codes are developed during the investigation and derived from the data being examined (ibid). The research at hand employs a Direct content analysis approach which uses both predetermined codes derived from theory as well as additional codes discovered through research.

\section{Selection Criteria}

Since amalgamation Toronto has become an ever more diverse "city of neighbourhoods" in terms of its sociocultural and demographic makeup as well as in its neighbourhood character, its built form and its range of established and newly formed communities. Ratepayers, residents, neighbourhood and community groups can be found in Toronto's oldest neighbourhoods such as Rosedale, Downsview, and Markland Wood and are beginning to spring up in the newer neighbourhoods of Cityplace and New Toronto among others. Unfortunately it is not within the scope of 
this research to investigate every neighbourhood group in the city. Groups tend to have varying levels of engagement with the City and sometimes do not have an established online presence. They can also form and demobilize quickly. As such, it is difficult to establish an exact figure of existing and operative groups in the city. To establish an appropriate research sample, City records, internet searches, and a scan of media sources provided a base set of approximately 200 groups in Toronto. This may in fact be a lowball figure, with reports in 2010 of closer to more than 320 groups (Stern et al., 2010).

From the initial set of 200 a sample of 10 groups were selected based on geographic representation, availability and quality of information, and evidence of engagement with City planning and governance processes ${ }^{2}$. An effort was also made to include representation from each of Hulchanski's "three cities" to bring greater diversity to the sample. In order to examine groups' activities and engagement with the City it was necessary to seek groups that showed evidence of being presently active in their communities, such as updated newsletters and websites.

For these reasons, two groups were chosen from each of the City's four community planning districts: Etobicoke, North York, Toronto and East York, and Scarborough. Two additional groups were also selected from Toronto and East York, as this is where neighbourhood groups seem be longer established and most active. Table 1 (following page) provides a breakdown of the selected groups by district and neighbourhood.

\footnotetext{
2 Neighbourhood groups may register with the City which maintains a mailing list that can be obtained by requesting the information through the City's customer service program, 311 Toronto.
} 


\begin{tabular}{|c|c|c|c|}
\hline Neighbourhood Group & $\begin{array}{l}\text { Community } \\
\text { Planning District }\end{array}$ & Ward & $\begin{array}{l}\text { Hulchanski } \\
\text { City }\end{array}$ \\
\hline Bayview Village Association (BVA) & North York & 24 - Willowdale & 1,2 \\
\hline $\begin{array}{l}\text { Downsview Lands Community } \\
\text { Voice Association (DLCVA) }\end{array}$ & North York & $\begin{array}{l}\text { York West (8) } \\
\text { York Centre (9) } \\
\text { York Centre (10) }\end{array}$ & 2,3 \\
\hline $\begin{array}{l}\text { Centennial Community and } \\
\text { Recreation (CCA) }\end{array}$ & Scarborough & Scarborough East (44) & 2 \\
\hline $\begin{array}{l}\text { Coronation Community and } \\
\text { Recreation Association (CCRA) }\end{array}$ & Scarborough & Scarborough East (43) & 2,3 \\
\hline $\begin{array}{l}\text { Harbord Village Residents' } \\
\text { Assocation (HVRA) }\end{array}$ & Toronto \& East York & Trinity Spadina (20) & 1 \\
\hline $\begin{array}{l}\text { The Pocket Community Association } \\
\text { (PCA) }\end{array}$ & Toronto \& East York & Danforth (30) & 1,2 \\
\hline $\begin{array}{l}\text { South Rosedale Ratepayers' } \\
\text { Association (SRRA) }\end{array}$ & Toronto \& East York & $\begin{array}{l}\text { Toronto Centre-Rosedale } \\
\text { (27) }\end{array}$ & 1 \\
\hline $\begin{array}{l}\text { York Quay Neighbourhood } \\
\text { Association (YQNA) }\end{array}$ & Toronto \& East York & Trinity Spadina (20) & n.d.a. \\
\hline $\begin{array}{l}\text { Mimico Residents' Association } \\
\text { (MRA) }\end{array}$ & Etobicoke York & Etobicoke-Lakeshore (6) & 2 \\
\hline $\begin{array}{l}\text { Thompson Orchard Community } \\
\text { Association }\end{array}$ & Etobicoke York & Etobicoke Lakeshore (5) & 1 \\
\hline
\end{tabular}

\section{STUDY LIMITATIONS}

The MRP is a professional research paper completed in a short time.

Accordingly secondary research methods were used. This limits the range of methods that could bring greater amount of detail to findings as well as verify the information collected. Importantly, as a large part of this research relied on material produced by the neighbourhood groups themselves, there are many voices and perspectives missing from this discussion. This includes residents who are not participating through 
a formalized organization and notably those who may be at odds with the viewpoints taken by the associations, or those still marginalized in planning practice. While this research considers collaborative techniques that call for greater diversity in voices, the method itself is limited to the often most vocal, and sometimes more privileged residents. Furthermore, this research was restricted to English sources due to the author's own language limitation. This is notable as just over $30 \%$ of residents in Toronto speak a language other than the official languages of English and French but were necessarily omitted from searches. In these ways this study perpetuates the status quo that privileges majority voices rather than furthering our understanding of the needs and experiences of the underrepresented. 


\title{
4. Findings
}

Responses and participation in urban planning process in a city characterized by socioeconomic polarization, growing cultural diversity, and irregular patterns of development manifests in various ways in different neighbourhoods across the city. This research sought to find ways in which traditional participation methods were being challenged in Toronto community planning by observing the involvement of neighbourhood groups in these processes. This section first examines the general community roles of neighbourhood groups and then discusses how the objectives and organizational structure of groups reveal how and why groups engage with the city and their capacity to contribute representative local knowledge to planning concerns.

\section{NeIGHBOURHOOD GROUPS}

\author{
MISSIONS, OBJECTIVES, FUNCTIONS
}

Goals and values of neighbourhood groups may be identified through missions, objectives, and value statements expressed in group constitutions. Just one of the 10 groups did not have a constitution available for analysis, however a membership brochure provided some information regarding the group's objectives. Common to most groups are statements that identify residents' welfare and the quality of life in neighbourhoods as main areas of concern. The first stated objective of the Downsview Lands Community Voice Association for example, is "To represent the interests and concerns of members of the Association with respect to any issues that arises within and surrounding the Association's boundaries..." (Downsview Lands Community Voice Association, 2008). The Coronation Community and Recreation Association similarly 
seeks "to further and promote the welfare of the residents of the area described above and its environs" (Coronation Community and Recreation Association, 2009). This is demonstrative of groups seeking an advocacy role within the community, which is further supported by instances of group action explored in the subsequent section. Most groups also endeavour to perform a mediatory role by providing information to residents regarding issues that may impact the community. Secondary to these concerns is the objective to "foster a sense of community," "encourage participation," and "civic empowerment" or enabling of residents. Neighbourhood beautification, liaising with local officials, and general "neighbourliness" are other common, though not prominent, goals.

What is interesting is the language used to specify the nature of the groups' advocacy role in the neighbourhood. It is language that indicates the character of the physical environment they envision in their community, and is thus of particular interest to community planners. Half of the groups state an interest in either "preserving" or "protecting" as well as "improving" or "enhancing" the character or quality of the neighbourhood. The initial objective for the South Rosedale Residents' Association (SRRA), for example is to "preserve and improve its present characteristic as a Residential Park area" (South Rosedale Residents' Association, n.d.) while the Harbord Village Association (HVRA) values "the stable, residential nature" of the neighbourhood and seeks "to preserve, protect and strengthen the characteristics which support this". This suggests that groups would likely be resistant to dramatic change in their communities. This facet, along with following insight into group activity, supports the 
premise that groups tend to engage primarily at the community planning level, especially with regards to public consultations regarding development proposals.

Mission statements further suggest that many groups are committed to representing the interests of residents (within defined neighbourhood boundaries) of their association. Such an objective implies that group activity must therefore involve effective interaction and communication among residents of the community in order to determine the nature of interests and extent of their concerns. This knowledge in turn informs the establishment of committees, prioritization of action, and delegation of resources. In three instances, groups make reference to community diversity in their mission or objective statements indicating a desire to be inclusive or respectful, or seeing diversity as a "key strength". Notable among these examples is The Pocket Community Association who provides group material to members in Chinese as well as English and welcomed a new local mosque to the community. These efforts are demonstrative of a group that truly recognizes the strength of diversity by forging partnerships with new community members, and incorporates their experiences and concerns in their representation of the community at large. This demonstrates that neighbourhood groups have the capacity to play a role in introducing newcomers to public participation in urban planning, and thus represent a potential approach to increasing newcomer participation. These kind of outreach efforts were rare, however, suggesting that perhaps this is not a priority for some groups or that they may be limited in tools or strategies to engage newcomer members of their communities. 


\section{GOVERNANCE STRUCTURE}

While not all neighbourhood groups have an established board of directors the majority of the preliminary sample and the entirety of the study sample were overseen by a Board of Directors (see Table 2, below). The establishment of a board of directors is a requirement for groups wishing to incorporate as a not-for-profit, as are the creation of group by-laws and objectives. These boards represent efforts to promote democratic decision-making within the groups as Boards play a role in deciding what and how issues will be pursued. Including executive members and excluding committees where present, the average size of these Boards is 11 members. The standard term length for sitting members is one year, with re-election occurring during the Annual General Meeting. The Downsview Lands Community Voice Association is unique in its use of a rotating 2-term method wherein 3 of six executive council positions are re-elected annually for the purposes of continuity.

\section{Neighbourhood Group}

Bayview Village Association

Centennial Community and Recreation Association

Coronation Community Association of West HIII

Downsview Lands Community Voice Association

Harbord Village Residents' Association

Mimico Residents' Association

South Rosedale Ratepayers' Association

The Pocket Community Association

Thompson Orchard Community Association

York Quay Neighbourhood Association
\# of Board Members ( $</=$ )

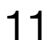

10

14

6

15

13

15

10

9

10

Average:

11

TABLE 2 - Size of BoARD of DiRECTORS by NeIGHBOURHOOd GROUP 
Board committees typically represent business such as Planning and Development, Safety, Environment, Traffic, Membership, and Outreach and Communications. Of the 10 groups, seven have formed committees to specifically address community interests. Two groups have established committees based on geographic rather than issuebased representation. The HVRA, for example, has representatives from the Northeast, Northwest, Southeast, Southwest and South Central areas of the neighbourhood. A similar method is used by the Downsview Lands Community Voice Association. The geographical approach allows representatives to share perspectives on a variety of neighbourhood matters with respect to their individual sector. Committees report back to the board on the issues and areas they represent as well as liaise with other interested non-board group members. The types of committees formed by groups suggests an increased interest in these areas as more energy and time is allocated to these concerns. There is a consistency in the concerns of the five groups utilizing an interest-based approach. The most common committee affairs can be generalized into the following categories:

- Planning and Development

- Environment (including conservation)

- Community Safety (including Community Police Liaison Committees, and Neighbourhood Watch) and;

- Communications and Outreach (including membership, distribution, and website committees)

Less common, but nonetheless prevalent committees among the groups are: 
- Traffic (including transportation and parking)

- Events and;

- Political issues (including municipal and government affairs).

Subcommittees also suggest when "the voice of the community" will be heard as the allocation of focus and resources to these categories suggests an active interest and potential capacity of groups to engage, or be engaged in certain topics.

\section{REPRESENTATION OF THE COMMUNITY}

For all of the effort of establishing a formal and democratic governance structure, neighbourhood groups present a challenge when it comes to representation. Typical of group mission statements and objectives was the goal of being the "voice of the community" but discussions of methods for consolidating community voices were rare. Representation was sometimes quantified in terms of household membership counts and qualified in terms of membership eligibility. Available counts ranged from 50 households to 1000 . Membership eligibility was often determined by residency within associations' bounds and payment of membership fees and business owners in the area were also eligible in the case of two groups. Average memberships costs are around $\$ 10$ annually. Two groups relied on general contributions from residents rather than charging members. The Thompson Orchard Community Association (TOCA) for example, states that they raise money from members when the need arises. The cost of annual membership fees thus ranged from free to $\$ 75$. While the higher number is an outlier, it raises important questions about who has access to the benefits of group membership within the community and whose voices are necessarily left out due to a 
potential cost barrier. Membership typically allows groups to pay for group communications, such as websites, email, and newsletters that convey information and updates on community events and issues. In most cases membership fees are promoted as allowing the organization to serve the community through the provision of activities and events, information and notices regarding local meetings and issues. For many groups membership also serves to allow the group to lobby the City on behalf of the community. Paying members are also afforded voting rights to participate in the election of executive board members, however it is not clear whether this means they are permitted to vote on specific issues. It is thus unclear whether members had any say in the issues that the group would allocate energy to, the position they would take in response to planning proposals, or whether this is delegated through elected executive board members.

\section{ACTION AND ACTIVITY}

Actions and activities were indicated by scanning groups' newsletters, websites, and local media reports. It was found that most activity focused in three areas: planning and development, environment, community engagement and safety (including traffic concerns). Some particularly unique activities of groups that promote engagement in the community and capacity building are the Bayview Village Association's (BVA) annual paper shredding event and the HVRA's Halloween pumpkin carving festival. Forging positive relationships in the community can not only serve to attract members but also provides the opportunity for the exchange of local knowledge. 
Organized community clean-up days were common to nearly all of the groups sampled. Often held in Spring, the event brings neighbours together in the spirit of community beautification and advances groups' advocacy missions to "enhance" and "beautify" their neighbourhoods. Some groups take on a more substantial stewardship role through their greening efforts by partnering with local organizations such as LEAF (Local Enhancement and Appreciation of Forests), partnering with student volunteers to provide lawn services, and providing information on invasive plant species such as the Emerald Ash Borer. Both the Pocket Community Association (PCA) and the HVRA were the most environmentally active groups of the sample, the latter of which has undertaken research to assess the environmental health of their community.

Groups also demonstrated partnership roles with local government in their responses to by-law infractions such as traffic and parking, noise, litter and of criminal activity such as vandalism. The PCA for example, provided information regarding bylaws through a column in their quarterly newsletter authored by "By-law Barb" for several issues. A more recent bulletin informs residents of a by-law that prohibits dogs from being off-leash at a local community park. The Harbord Village Association addresses graffiti "tags" in the laneways of the neighbourhood by providing paint to neighbours, and has also tackled this issue by partnering with local artists to paint murals on rear garages. Community Police Liaison Committees (CPLC) allow groups to be able to directly report neighbourhood misconduct, such as TOCA who have taken a stance against "rascals" in their community (Thompson Orchard Community Association, May 2 2015). They are a special sort of "eyes on the street" who watch for behaviour that mar and hinder their vision of neighbourhood consonance. 
Most predominant among the groups, however, was their extensive involvement in neighbourhood development and community planning. This is evident in the abundant updates on websites and in newsletters and published letters from local councillors regarding local development projects in the neighbourhood. The home webpage of the Mimico Residents' Association (MRA) features a news feed of posts regarding current development activity, including development applications and the recently created Mimico-by-the-Lakeshore Secondary Plan. The MRA also provides a calendar of upcoming meetings, many of which are community consultations regarding development proposals and the aforementioned Secondary Plan. Groups are active in varying functions of planning and development including re-zoning applications and official plan amendments and committee of adjustment items. Associations who register with the city receive notices on Committee of Adjustment items, such as minor variance and development applications. In examining group responses to these materials it is clear that mobilization around development and planning occurs often in response to change that is out of character from the present neighbourhood. In a letter written to the Community Council of North York, The Bayview Village Association states their opposition to what they characterize as "townhouse creep" (Bayview Village Association, October 2015). They state the development "does not respect or reinforce the existing physical characteristics" of their community. This corresponds with the sentiments of other groups concerned with maintaining a stable environment.

Some groups, however, do present a more neutral tone in their presentation of community development materials. The Coronation Community and Recreation Association, for example, posts details regarding meetings and how residents may 
become involved, but do not state a position regarding the matter. Instead, they instruct residents to direct comments and concerns to their local councillor themselves (Coronation Community and Recreation Association, March 2016; ibid April 2015).

Actions at the community level thus tend to demonstrate partiality toward previously delineated conservative, liberal, or progressive political philosophies (Peterman 2000). Groups such as those concerned with protecting the neighbourhood character of their communities, opposing townhouses and residential growth, for example, demonstrate a more conservative position while other groups who participate proactively in planning initiatives are characteristic of more liberal and sometimes progressive attitudes. The SRRA, BVA, and TOCA are groups who exemplify more protectionist positions in relation to community development. The BVA, in resisting townhouse development, the SRRA in establishing a Heritage Conservation District across the neighbourhood, and TOCA who formed specifically in response to the growing number of "monster homes" in the neighbourhood (Thompson Orchard Community Association, n.d.). Other groups are more liberal in partnering with government and planners to achieve their community goals. This includes the HVRA who, through efforts to revitalize the pedestrian realm of a major street in their neighbourhood influenced the establishment of a Public Realm office which is part of the Transportation Services Division. The range of activity of these groups and their responses to community change thus suggests that groups in Toronto exist on a spectrum of engagement orientations, rather than being exclusively NIMBY, or communitarian in nature. 


\section{Neighbourhood Groups and Community Planning in Toronto}

As previously outlined, municipalities are required to engage the public when amendments to the Official Plan, Zoning by-laws, or Plans of subdivision are being considered. The Community Planning model in the City of Toronto also encourages dialogue with residents and stakeholders who take active interest in planning processes. This coincides with the tendency of neighbourhood groups to engage most often at the Community Planning level, however there are at least five levels, or forums, through which public engagement in planning processes occurs in Toronto: city-wide, neighbourhood-based, site-specific, special studies, and special outreach initiatives (City of Toronto, 2013). These all typically occur in the context of proposed change. City-wide processes most often include Official Plan reviews, and have recently included other opportunities to participate in decisions with regards to more specific issues. Feeling Congested? for example was conducted as part of the City's Official Plan Review and involved extensive consultation across the city. The campaign employed online feedback tools, discussion panels, working sessions as well as traditional public meetings. Other processes include Toronto's Tall Buildings Guidelines, Harmonized Zoning by-law and the Toronto Green Standard.

As demonstrated by the scan of group activity and monitoring of Committee of Adjustment and development proposals, neighbourhood groups are regularly involved at the community planning level. This includes neighbourhood-based (such as Area Studies, Secondary Plans, and Heritage Conservation Districts) and site specific planning processes (such as those triggered by development applications). Groups can also be the instigator of these processes. Mimico Residents' groups, for example, 
partnered with their councillor to bring about the Mimico 20/20 Revitalization Study. More often than not, groups are also behind local Heritage designations, manifesting the protectionist objectives of some organization's missions. Special planning studies also typically involve neighbourhood groups. The YQNA for one has long been involved in waterfront revitalization efforts and the Billy Bishop Island Airport expansion.

The format for consultations depends on relevant regulatory preconditions, the planning issue to be discussed, existing data, previous or related engagements, stakeholder capacity and demographics, and participation barriers (City of Toronto, 2011). Based on these variables a method for consultation is determined by City staff including community planners and local councillors. Methods include a range of structured and semi-structured processes that vary in the degree and type of interaction between staff, third-party consultants and participants. Simple events such those regarding projects in the infant stages of the process and initial development consultations are often conducted by City planning staff with relevant Councillor(s) and their constituent assistants. These are fairly structured affairs in the form of open house or "town-hall" meetings in which staff address questions and concerns raised by participants. These methods are fairly limited in terms of two-way communication, but do allow for some exchange of technical and local knowledge between staff and stakeholders.

With matters that involve more complex topics or those that require greater numbers and diversity in stakeholders, more deliberate and attentive strategies are necessary. These are often multi-phased and can employ a variety of tools to engage 
and exchange knowledge. Workshops, charrettes ${ }^{3}$, site tours, and working groups are common methods used in community planning that allows for the input of multiple stakeholders. These processes permit a great deal more two-way communication and group interaction often over an extended period of time. These environments are much more conducive to the DIAD conditions for collaboration because they attempt to collect diverse interests in a process of social learning.

The Chorley Park Trail Design Stakeholder Working Group was one such effort that was demonstrative of a collaborative exercise to find a design solution related to local park improvements involving a diverse range of stakeholders. The process was overseen by a third-party consultant. Participants included City staff, residents, neighbourhood associations, user groups, nature enthusiasts, dog owners and those representing different movement abilities and performance. Over the course of close to a year, three meetings were held with the 30 members. The meetings involved a site tour and group discussion facilitated by the consultant, design charrette activity, and multiple feedback sessions to share responses from the City. Individual meeting summaries and outcomes, prepared by the consultant were made publicly available. The final outcome exhibits the aggregated knowledge of participants, despite not being the "ideal" conclusion to the process to some.

For more extensive city-wide or ongoing engagement the City has established advisory and liaison committees that inform and advise the City on the operation and implementation of projects and facilities. These often occur in the context of public

${ }^{3}$ Charrettes are extensive and collaborative processes typically employed to generate design solutions to planning matters (Sanoff, 2000). Neighbourhood visioning, parks and street studies, and transportation planning are common activities in which charrettes can draw on the creative capacity and local knowledge of stakeholders to inform the planning decision. 
works and infrastructure, such as the Highland Creek Wastewater Treatment Plant Biosolids Management study which involved four local neighbourhood groups, including the CCA and CCRA. For the most part these groups are formed to oversee a project once a decision has been made and provide feedback regarding project and facility performance rather than in the site planning and proposal stages. These are typical in instances where secondary regulatory bodies are involved such as the Toronto and Region Conservation Authority or the Ministry for the Environment and Climate Change. Local residents are often included as their first-hand experience of the facility or infrastructure is essential to its ongoing performance. Committees often allow for substantial interaction between citizens and government, however in situations where groups are closed to the general public the question of whose voices are left out of the process are raised. It is important in these cases that participants be conduits to procure and disseminate knowledge to the local communities they represent.

As part of the city's objectives to build civic capacity, improve planning processes, increase participation and facilitate city building the City has expanded its outreach efforts. This includes the "Planners in Public Spaces" (PiPs) initiative and Chief Planner Roundtables (ibid). In the case of the latter, and as part of the Growing Conversations project, Resident Association Roundtables were held in each of the Community Planning districts in 2014. Associations from each area were invited to participate and provide input into improving Toronto's engagement processes. The insights provided from these meetings, as well as the lessons learned from Toronto's engagement with neighbourhood groups point to the challenges hindering effective engagement between the City and its residents. These included issues related to the 
accessibility and complexity of planning processes in the city, effective and timely communications, and general apathy toward or lack of confidence in the planning process.

Toronto has attempted to improve on the transparency of decision-making and communications with the public through supplementing engagement practices with online tools and educational platforms. The use of online tools by the city demonstrates a willingness to employ experimental and untraditional means of communication to meet its engagement goals. These tools can be effective in reaching those for whom English is not a primary language through a web browser extension that can translate material. Moreover, these tools are one signal that Toronto is seeking participatory approaches in urban planning that go beyond "status quo" methods of open houses, consultations, and working groups, to reach a broader audience of citizens who may not be able to access these meetings due to language barriers, time constraints, or simply prefer the convenience and comfort of participating from home. Online tools and social media are often used in tandem with face-to-face engagement methods and have the potential to increase opportunities for participation when used effectively. These tools provide an opportunity to close the gap of representation left open by neighbourhood groups that may only represent a pocket of residents within the community.

Get Involved is the City's web portal for public consultations. It features three options for viewing information: an event calendar, map and search feed. It is augmented by a twitter account (@GetInvolvedTO) that relays updates and notices about consultation in the city. Users can locate past and present consultations with a 
choice to filter results by issue, and city-wide or location-specific events. Search results link to project pages for information about the process to date, future events and relevant city contacts. Although similar in appearance, there are some inconsistencies between the format and content of the pages that make it difficult to find relevant material, if it is available at all. The Toronto Meeting Management Information System is another search tool that allows public access to information on meeting agendas from various committees and departments of City Council. These include documents related to council decisions such as background reports and some communications files. Together these search tools enable residents to more effectively and actively engage in community planning by making the process convenient and accessible.

In addition to these search tools, the public can participate online using Toronto's IdeaSpace platform. Users can respond to questions posted by the City either by "commenting" or posting an "idea". The platform allows for greater participation and some collaboration by allowing participants to comment and "upvote $^{4 "}$ each other's ideas. However, the extent of collaboration here is questionable, since community input far outweighs the responses and communication from the City. Further study as to how outcomes are affected by this kind of community input is necessary, but unfortunately out of the scope of the research at hand.

The City's engagement efforts represent an array of tools and strategies that can be employed to achieve public participation objectives such as those identified on the

\footnotetext{
4 "Up-voting" is a means to track the popularity of an idea or comment by positively ranking an item. The more positive "votes" an item receives, the higher in will appear in a given forum. In the case of IdeaSpaceTO, users can view items in rank either by popularity or date of posting.
} 
IAP2 spectrum. The Get Involved portal, for example, is an information-sharing tool that can assist the public in understanding city issues. It fulfills the City's responsibility to keep the public informed as well as enabling citizens to participate by providing resources to understand the planning process and become involved in face-to-face events. The Ideaspace platform, at the same time, provides a system for obtaining feedback. However the platform does not provide a weblink to council decisions or indicate how feedback will be, or has been, used or implemented into City Planning decisions. In "consulting" and "involving" the public, according to the IAP2's spectrum of participation, it is integral that participatory administrators ensure feedback, concerns and issues are reflected in the development of alternatives for further consideration and in decisions.

These findings indicated that Toronto's Engagement strategies to involve the public in planning processes are making strides to move beyond status quo approaches such as public meetings dictated by planning experts to more actively involved residents through more interactive methods both on the ground and on the web. These efforts are a first step at reaching out to underrepresented groups by establishing working groups and empowering members with knowledge and resources to actively participate in planning processes. Growing Conversations, however is only in its initial stages, and further work will have to build on these first steps to inform and involve by providing consistent and accessible methods to retrieve and understand how feedback has been implemented into planning decisions. These findings also indicate that neighbourhood groups represent an opportunity for the City to build on 
collaborative relationships in the city, as in many cases these groups demonstrate the capacity and willingness to establish working partnerships. 


\section{Conclusions and Recommendations}

This research endeavoured to learn how Toronto planning approaches to public engagement go beyond traditional methods for participation by facilitating the production and procurement of local knowledge. It set out to learn how agents of local knowledge (here exemplified by neighbourhood groups) produce, collect, and convey such knowledge in community planning processes and how such processes contribute or restrain the exchange of local and technical knowledge. This research makes the following five major conclusions: First, there are both groups that reinforce the NIMBY stereotype, and many that challenge the label. The activity of neighbourhood groups is situated on a spectrum that serves predominantly private interests on one end and community or city interests on the other. In Toronto there exists groups that demonstrate conservative tendencies to protect property rights and values sometimes at the cost of equitable planning, as in the case of the Chorley Park Trail project. At the same time there are groups that are key community builders who welcome newcomers, as in the case of the PCA, and who entreat government to assist neighbourhoods in achieving their green space goals. Second, while neighbourhood groups play an active role in neighbourhood advocacy and community building, it remains unclear whose voices are represented when these groups engage in planning decisions. As there is no clear mechanism for qualifying as "the voice of the community," and as the multitude of voices in Toronto grows increasingly diverse, it remains a great challenge to City staff to determine the extent to which neighbourhood groups do, in fact, represent the interests of the community as a whole. The challenge has significant implications in a City such as Toronto, as Edward Keenan asserts 
"Gauging their legitimacy is actually necessary because opposition to change and growth can, in the aggregate, make cities less affordable [...] less able to handle growth [...] and more unequal" (2016). Third, while the City's engagement efforts represent higher degrees of collaborative potential during semi-structured, multi-phased processes such as working groups, charrettes, and workshops, public consultation meetings in the form of open houses and town-halls are often criticized for lacking opportunities for two-way dialogue and outcomes thus rarely demonstrate implementation of local knowledge. This is significant in the case of neighbourhood groups who often engage at this level. Fourth, the City's engagement efforts are conducive to procuring local knowledge but are challenged in demonstrating the implementation of this knowledge as it is often an amalgam of diverse interests, technical requirements as well as being subject to the decision-making authority of local politicians. Similarly, engagement outcomes lack a consistency that could be effective in the public's understanding of how their input was considered. Fifth, given the nature of community planning in Toronto, engagement has been more effective when groups tend toward a liberal view of community organization and empowerment, that is, when they see government and other participants as interdependent partners in the process.

Growing Conversations exhibits considerable potential to incorporate a greater number of diverse stakeholders: residents who can provide crucial knowledge of the communities they live in and who may have innovative proposals to the challenges facing Toronto City Planning. These are the challenges that put pressure on communities, strain city resources and require collaborative strategies to incorporate 
both technical and local knowledge, and promote the interaction of deal-makers, dealbreakers, and the public. Cynical attitudes toward neighbourhood groups ("those NIMBYs") will not serve the process. Besides the fact that these groups have demonstrated their staying power, these groups play positive roles within the community, roles that city planning simply would not be able to replace.

Neighbourhood groups further present a resource to introduce newcomers and community members to planning processes, and can mobilize citizens to help implement programs and plans. Perhaps, then, what is required is a new conception of the role of neighbourhood groups in planning processes: not as "the voice of the community" but as local knowledge agents. Such a designation has functional implications indicative of the "expertise" that can empower citizens to participate and is crucial to designing and implementing effective community plans.

\section{RECOMMENDATIONS}

This research concludes with recommendations directed to community planners, councillors, and neighbourhood groups to assist in addressing the challenges of public engagement and procurement of local knowledge.

\section{COMMUNITY PLANNING}

Neighbourhood groups and Toronto City Planning often become polarized when consultation and planning projects are seen to conflict with community interests. Working relationships take time to develop, and only when groups see each other as interdependent in achieving respective goals. The Resident Association Roundtables 
are an effective measure in demonstrating Community Planning's willingness to listen to the concerns of residents and receive feedback on improving the process. These roundtables should occur annually and seek to increase turnout (the North York district roundtable turnout was a meagre total of three). This could be incentivized by offering workshops on planning tools that would allow groups to proactively seek community goals such as the Heritage Designation process, Urban Design Guidelines, and other material. A handbook or web portal that provides information on this "tool box" (which are mostly already available online).

Community Planning might also consider developing a more consistent feedback format for communicating engagement outcomes to participants and the wider public. The City often employs third-party consultants to administer these processes, who prepare summary reports, available online, of what was communicated during the public consultation process. However these documents are not consistent between different parties, as are the webpages where the documents may be found. City Planning should develop a consistent format for consultation webpages to simplify sharing this information with constituents.

\section{COUNCILLORS}

It is quite often the case that Toronto City Councillors keep a running list of neighbourhood groups and they are quite often the point of first contact for neighbourhood groups. In some cases this means they are responsible for introducing groups to planning processes and should thus be knowledgeable of engagement opportunities and tools available to groups. Councillors should continue to seek formal 
introductions from these groups that include an introductory letter of their mission statement and scope of membership. Acknowledging the group's role as local knowledge agents and committing to developing mediation skills to effectively engage participants in planning processes are other ways that they can promote collaboration. Finally, councillors should insist on pre-consultation community meetings with developers in order to gain their support for projects which promotes civic trust in government who may be seen as a partner in seeking timely provision of material in order to more effectively engage with the project.

\section{NEIGHBOURHOOD GROUPS}

As has been reiterated throughout this study, the greatest asset of neighbourhood groups in Toronto Community Planning is their first-hand knowledge of the communities and spaces they interact with daily. Given that City Planning's engagement efforts increasingly provide opportunities for this knowledge, a new role for neighbourhood groups presents itself: as local knowledge agents. This is not the same as "the voice of the community" that is thus far unsubstantiated through group functions and activity. Groups wishing to empower their voice through diversifying their membership should record outreach activities to community members and organizations, including youth members. Providing materials in other predominant languages of the community may also be appropriate in some neighbourhoods. Online tools may also be employed to effectively engage more members. The online distribution of newsletters and materials can allow groups to save on printing costs, and serves to promote the activity of groups to a wide audience. Other tools can be 
used to garner community responses and input on issues to be represented by the group at public meetings. Google docs, for example allows one to create polls and surveys that can aggregate feedback from community members and can inform group decision-making and feedback in engagement activities. The sharing of local knowledge among members is essential to maintaining strong community bonds and meaningful engagement in community planning.

\section{FUTURE RESEARCH}

To gain a full understanding of how neighbourhood groups are being engaged by the city would require a great amount of observational analysis of public meetings, workshops, and other participatory events hosted by the city. How neighbourhood groups organize, operate and engage within and outside of their associations would benefit from key informant interviews that could both verify information collected and provide additional first-hand personal accounts of participatory experiences. This kind of multi-method research is unfortunately outside the scope of the research at hand, but would nonetheless enhance our understanding of neighbourhood groups and communicative actions taking place in public participation processes. 


\section{Appendix A: Toronto Official Plan Policy for Public Involvement}

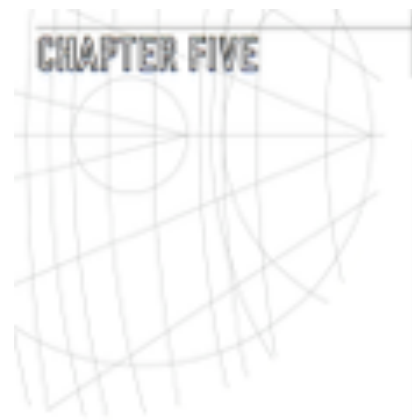

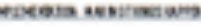

\section{Policies}

1. Auble inchenent

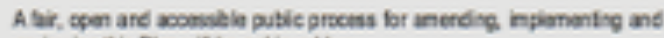
fevineing this Pin wil be achieved by.

a) encosraghpartciakion by al segrents of the peoulaion, recogiang

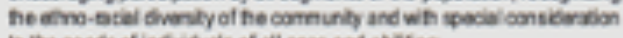
bo the needs of indidasis of al ages and ablites

b) promating ornmunly avareness of pleming laves and deckions.

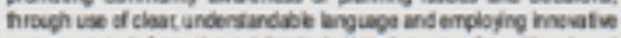
prooksses to infom the pablic, including the se of trobiond and elodicuic mola wet

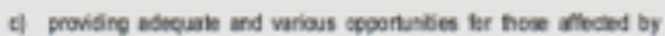

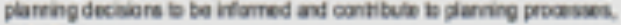
indueing

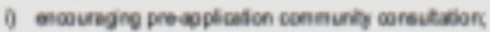

i) helding a least one crnnunky neetry in the afhcled ana, in

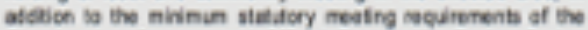

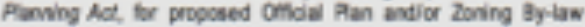
anenemerts ptser bo aforova:

if esuring that iffornetion and materiab subritud is the Cry as. part of a updicinon dump the couse of ts proosing an made aulabl to he putic; and

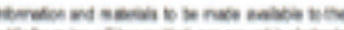

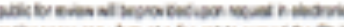

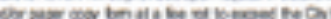

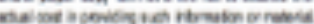

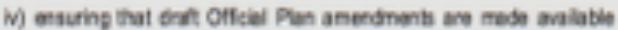
E the palic br revies a leas bonty deys pror bo Easibry

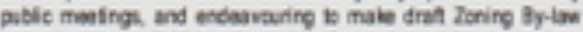
anendrents evalable to he pabic for nevien at lasat wa days

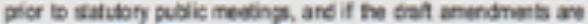

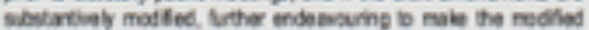

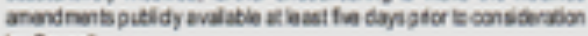
by Courel.

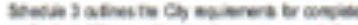

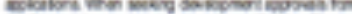

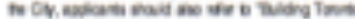

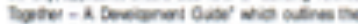

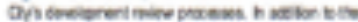

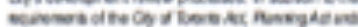

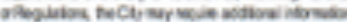

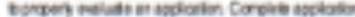

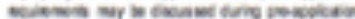
nonts

SS INTERPRETATION

Te follewing policies provide guidanee for the undestanding and interpetation af the bext, maps schedules figures and images of this Man.

sa

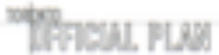




\section{Appendix B: International Association for Public Participation 2 Spectrum}

\section{lap2 public participation spectrum}

developed by the intemational association for public participation

\begin{tabular}{|c|c|c|c|c|c|}
\hline & NFORM & CONSULT & INWOLYE & COUABORATE & EMPOWER \\
\hline $\begin{array}{l}\text { PUBLIC } \\
\text { PAFIICIPATION } \\
\text { GOAL }\end{array}$ & $\begin{array}{l}\text { To provido } \\
\text { the public } \\
\text { with balanced } \\
\text { and objective } \\
\text { information to } \\
\text { assist them in } \\
\text { understanding } \\
\text { the problems, } \\
\text { alternasives andior } \\
\text { solutions. }\end{array}$ & $\begin{array}{l}\text { To obtain public } \\
\text { foedback } \\
\text { on andysis, } \\
\text { alternatives andior } \\
\text { decision. }\end{array}$ & $\begin{array}{l}\text { To work diroctly } \\
\text { with the public } \\
\text { throughout the } \\
\text { process to ensure } \\
\text { that public issues } \\
\text { and concerns } \\
\text { are consistently } \\
\text { understood and } \\
\text { considered. }\end{array}$ & $\begin{array}{l}\text { To partner with } \\
\text { the public in each } \\
\text { aspect of the } \\
\text { decision including } \\
\text { the development of } \\
\text { altemasves and the } \\
\text { identification of the } \\
\text { proferred solution. }\end{array}$ & $\begin{array}{l}\text { To placo final } \\
\text { docision-making } \\
\text { in the hands of } \\
\text { the public. }\end{array}$ \\
\hline $\begin{array}{l}\text { PROMISETO } \\
\text { THE PUBLC }\end{array}$ & $\begin{array}{l}\text { We wil keep you } \\
\text { informed. }\end{array}$ & $\begin{array}{l}\text { We wil keep you } \\
\text { informed, listen to } \\
\text { and ackonowledge } \\
\text { conceens and } \\
\text { provide foedback } \\
\text { on how public input } \\
\text { influenoed the } \\
\text { decision. }\end{array}$ & $\begin{array}{l}\text { We will work with } \\
\text { you to ensure that } \\
\text { your concerns } \\
\text { and issues are } \\
\text { directly noflected } \\
\text { in the alternatives } \\
\text { developed and } \\
\text { provide feedbsck } \\
\text { on how public input } \\
\text { imlluenced the } \\
\text { decision. }\end{array}$ & $\begin{array}{l}\text { We will look to you } \\
\text { for direct advice } \\
\text { and innovation } \\
\text { in formulating } \\
\text { solutions and } \\
\text { incorporate } \\
\text { your advise and } \\
\text { recommendations } \\
\text { into the decisions to } \\
\text { the maximum extent } \\
\text { possible. }\end{array}$ & $\begin{array}{l}\text { We wil implement } \\
\text { what you decide. }\end{array}$ \\
\hline EXAMPLETOOLS & $\begin{array}{l}\text { - Fact sheets } \\
\text { - Wobsithes } \\
\text { - Open houses }\end{array}$ & $\begin{array}{l}\text { - Public commant } \\
\text { - Focus groups } \\
\text { - Surveys } \\
\text { - Public meetings }\end{array}$ & $\begin{array}{l}\text { - Workshops } \\
\text { - Delberate polling }\end{array}$ & $\begin{array}{l}\text { - Cificen Advisory } \\
\text { commintees } \\
\text { - Consensus- } \\
\text { bulding } \\
\text { - Participatory } \\
\text { docicion-making }\end{array}$ & $\begin{array}{l}\text { - Citicen juries } \\
\text { - Ballots } \\
\text { - Delegated } \\
\text { decisions }\end{array}$ \\
\hline
\end{tabular}




\section{Appendix C: Toronto City Planning Approvals Process}

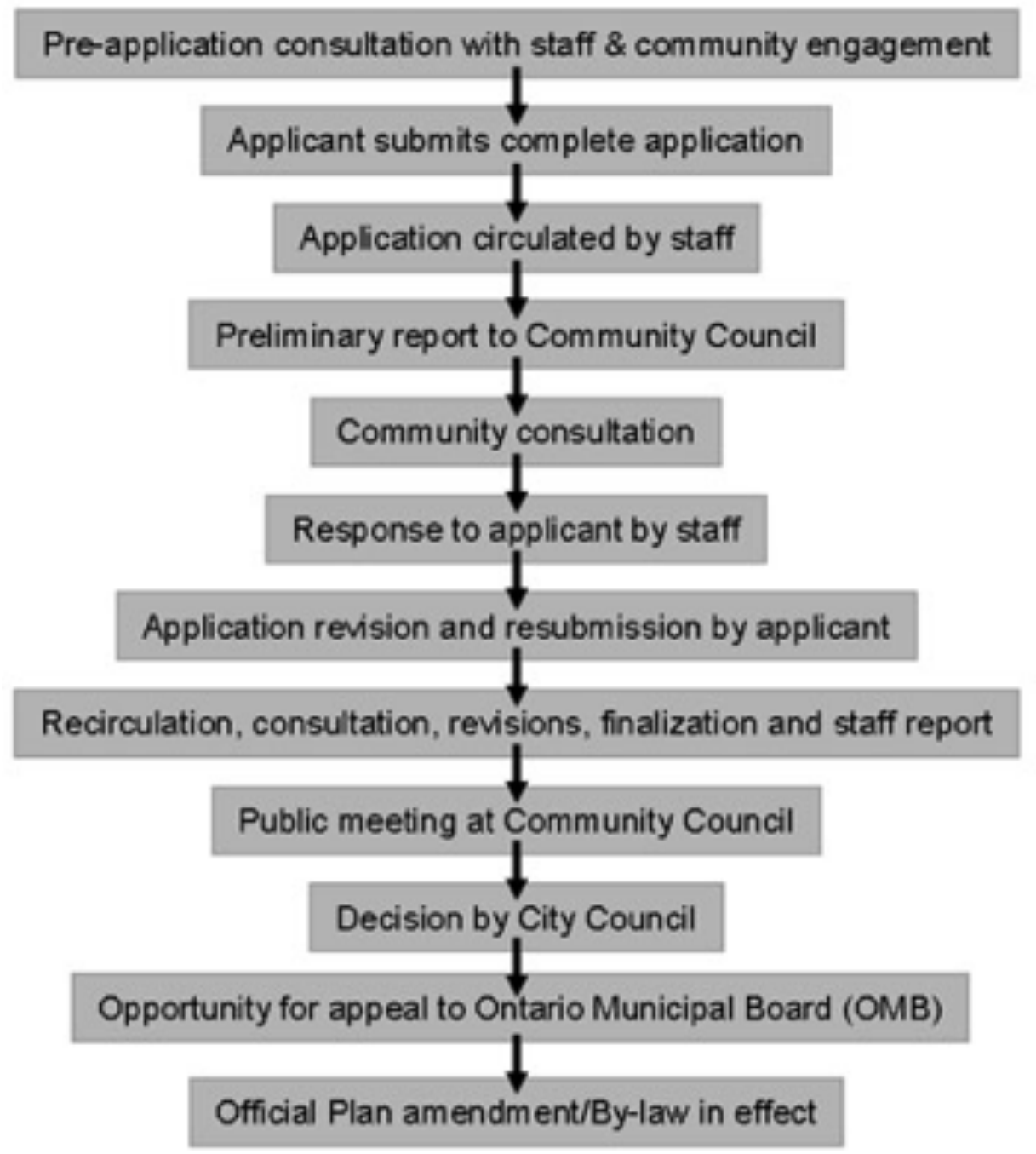




\section{References}

Bayview Village Association. June, 2015. Bayview Village Association BY-LAWS. Retrieved from http://bayviewvillage.org/aboutus.html

Bayview Village Association. October, 2015. Bayview Village Association Newsletter. Retrieved from http://bayviewvillage.org/newsletters.html

Burchfield, M. (2014). Implementing Residential Intensification Targets: Lessons from Research on Intensification Rates in Ontario. Toronto: Neptis Foundation.

Campbell, H., \& Marshall, R. (2002). Utilitarianism's Bad Breath? A Re-Evaluation of the Public Interest Justification for Planning. Planning Theory, 1(2), 163-187. doi: $10.1177 / 147309520200100205$

Centennial Community and Recreation Association. (n.d.) Centennial Community and Recreation Association (CCRA) Constitution and By-laws. Retrieved From http:// www.ccranews.com/constitution.html

City of Toronto. (n.d.) Growing Conversations - Youth Engagement Strategy. Retrieved From http://www1.toronto.ca/wps/portal/contentonly?vgnextoid=341892aafecdf 410VgnVCM10000071d60f89RCRD

City of Toronto. (2011). Corporate Engagement Strategy-Divisional and Program Engagement Supports. Staff Report. From City Manager to City Council. June 30, 2011. Ref No. N/A.

City of Toronto (2013). Improving the Community Planning Process Through Public Engagement. Staff Report. From Chief Planner and Executive Director, City Planning to Planning and Growth Committee Management. November 14, 2013.

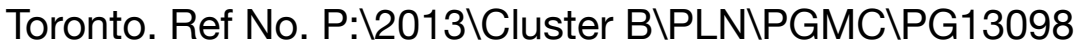

Coronation Community Association. October 6, 2009. Coronation Community Association of West Hill Constitution 2009. Retrieved from http:// coronationca.com/CCA_about.php

Coronation Community Association. April 2015. Transporation Report. Web post. Retrieved from http://www.ccranews.com/Committee-Reports-1.html

Coronation Community Association. March 2016. Planning Report. Web post. Retrieved from http://www.ccranews.com/Committee-Reports-1.html

Day, D. (1997). Citizen Participation in the Planning Process: An Essentially Contested Concept? Journal of Planning Literature, 11(3), 421-434. doi: $10.1177 / 088541229701100309$ 
Desfor, G., et al. (2006). From surf to turf: No limits to growth in Toronto? Studies in Political Economy, 77, 24. Retrieved from http://resolver.scholarsportal.info/ resolve/07078552/v77inone/nfp_fsttnitgit

Downsview Lands Community Voice Association. August 6, 2008. Constitution. Retrieved from http://www.downsviewlandscommunity.org/index.html

Faga, B. (2010). Focus on Civic Engagement. In G. H. e. al (Ed.), Local Planning Contemporary Principles and Practice (pp. 234-242). Washington, D.C.: ICMA Press.

Habermas, J. (1981). The Theory of Communicative Action: Reason and the Rationalization of Society. Boston, MA: Beacon Press.

Halvorsen, K. E. (2003). Assessing the effects of public participation. Public Administration Review, 63(5), 535-543.

Harbord Village Residents' Association. (n.d.) About the Harbord Village Residents' Association. Retrieved From http://harbordvillage.com/about

Hollett, J. (2014). Civic Tech for Civic Voice: A Digital Engagement Primer. Retrieved from http://atkinsonfoundation.ca/wp-content/uploads/2014/10/ Atkinson_CTR_FA_101614_Digital.pdf

Hulchanski, J. D. (1974). Citizen Participation in Planning: A Look at the Metropolitan Toronto Transportation Review. Plan, 14(1), 23-29.

Hulchanski, J. D., \& University of Toronto. Cities, C. (2010). The three cities within Toronto: income polarization among Toronto's neighbourhoods, 1970-2005: Cities Centre, University of Toronto.

Innes, J. E., \& Booher, D. E. (2004). Reframing public participation: strategies for the 21st century. Planning Theory \& Practice, 5(4), 419-436. doi: $10.1080 / 1464935042000293170$

Innes, J. E. B., D.E. . (2010). Planning with Complexity: An introduction to collaborative rationality for public policy. New York, NY: Routledge.

International Association for Public Participation (n.d) Foundations of Public Participation. Brochure. Retrieved from http://iap2canada.ca/

Jacobs, J. (1961). The death and life of great american cities. Random House. 
Kamizaki, K., \& Social Planning, T. (2013). Linking community organizing with policy change initiatives: implications for future community practice in Toronto: Social Planning Toronto.

Longo, L. F., Mascarin, J., \& Ontario. (2008). A comprehensive guide to the City of Toronto Act, 2006 (Vol. 2008): LexisNexis Canada.

Margerum, R. D. (2011). Beyond Consensus. Cambridge, Massachusetts and London, Englend: The MIT Press.

Ministry of Municipal Affairs and Housing (1990) The Planning Act. produced by Provincial Planning Policy Branch.

Mimico Residents' Association. March 20, 2014. A By-law Relating Generally to the Transaction of the Affairs of the Mimico Residents' Association. Retrieved from http://www.mimicoresidents.ca/about-the-mra/

Moore, A. A. (2013). Planning politics in Toronto: the Ontario Municipal Board and urban development: University of Toronto Press.

Neuman, W. L., \& Robson, K. (2012). Basics of social research: qualitative and quantitative approaches (Vol. 2nd Canadian): Pearson Allyn and Bacon.

Ontario. Companies, B., \& Ontario. Charitable Property, D. (2000). Not-for-profit incorporator's handbook: The Branch.

Peterman, W. (2000). Neighborhood planning and community-based development: the potential and limits of grassroots action: Sage.

Reid, Dylan. (2010, January 10) "New Toronto Public Realm Office Off and Running" Spacing Toronto. Retrieved from http://spacing.ca/toronto/2009/01/10/newtoronto-public-realm-office-off-and-running/

Rosen, G., \& Walks, A. (2015). Castles in Toronto's Sky: Condo-ism as Urban Transformation. Journal of Urban Affairs, 37(3), 289-310. doi:10.1111/juaf.12140

Sanoff, H. (2000). Community participation methods in design and planning: Wiley.

Schwartz, H. (2009). Toronto Ten Years after Amalgamation. Canadian Journal of Regional Science, 32(3), 11. Retrieved from http://www.cjrs-rcsr.org/archives/ 32-3/SCHWARZ-final.pdf

South Rosedale Residents' Association. (n.d.) Constitution. Retrieved from http:// southrosedale.org/about-us/governance/ 
The Pocket Community Association. January 24 2013. The Pocket Community Association Constitution and By-laws. Retrieved from http://www.thepocket.ca/ who-we-are/what-is-the-pca/

Thompson Orchard Community Association. May 2 2013. TOCA Constitution and Bylaws. In Facebook [Group Page]. Retrieved from https://www.facebook.com/ ThompsonOrchard/

Thompson Orchard Community Association. May 2 2015. Meeting with Community Police about peace-disturbing youth in TOCA area. In Facebook [Group Page] Retrieved from https://www.facebook.com/ThompsonOrchard

Thompson Orchard Community Association. (n.d.) About- Thompson Orchard Community Association. In Facebook [Group Page]. Retrieved from https:// www.facebook.com/ThompsonOrchard/info/?tab=page_info

Vandebelt, D. (2003). Involvement of Citizens and Neighbourhood Groups in Municipal Decision-making: A Review of the Llterature. Waterloo.

Wynveen, A. (2015). Beautiful day in the neighbourhood? Unpacking the complexities of residents' associations and their role in the planning process. Current Issues Paper, Unpublished. Geography. University of Toronto. Toronto.

York Quay Neighbourhood Association. March 8, 2011. York Quay Neighbourhood Association Constitution. Retrieved from http://yqna.ca/?page_id=26 